\title{
SPATIAL PATTERNS AND RELATIONS WITH SITE FACTORS IN A CAMPOS GRASSLAND UNDER GRAZING
}

\author{
FOCHT, T. and PILLAR, V. D. \\ Departamento de Ecologia, Universidade Federal do Rio Grande do Sul, CEP 91540-000, Porto Alegre, RS, Brazil \\ Correspondence to: Valério DePatta Pillar, Departamento de Ecologia, Universidade Federal do Rio Grande do Sul, \\ Avenida Bento Gonçalves, 9500, CEP 91540-000, Porto Alegre, RS, Brazil, e-mail: vpillar@ecologia.ufrgs.br \\ Received January 14, 2002 - Accepted April 12, 2002 - Distributed August 31, 2003
}

(With 2 figures)

\begin{abstract}
Spatial distribution patterns and their relations with environmental factors at different scales were identified in ca. 100-ha grassland under cattle and sheep grazing, in Eldorado do Sul, RS, Brazil $\left(30^{\circ} 05^{\prime} \mathrm{S}, 51^{\circ} 40^{\prime} \mathrm{W}\right)$. The field survey used $1380.5 \times 0.5 \mathrm{~m}$ quadrats located systematically on transects along relief gradients. The quadrats were arranged in groups of 3 contiguous quadrats, which were pooled for the analysis, thus forming 46 quadrats $1.5 \times 0.5 \mathrm{~m}$, in this way defining two observation scales. Vegetation description involved recording the presence and the visual estimation of coverabundance of species in each quadrat. A total of 148 species belonging to 30 families was detected. The environmental conditions at each site were described by 30 variables related to soil chemical and physical properties, slope, exposure and relief position. Data analysis used cluster analysis, evaluation of group partition sharpness, ordination, significance of ordination axes, evaluation of environmental congruence and randomization testing. The results of the analysis with 46 quadrats supported those found with 138 quadrats. The vegetation patterns in the study area are associated to relief position and other related factors such as soil moisture. Two clearly defined grassland community types were detected, one occurring on the slopes and another on the wet lowlands.
\end{abstract}

Key words: grassland vegetation, spatial distribution patterns, environmental factors, scale, statistical analysis.

\section{RESUMO}

\section{Padrões espaciais e suas relações com fatores de ambiente de um campo pastejado}

Padrões de distribuição espacial e suas relações com fatores ambientais, em diferentes escalas, são identificados em uma área de vegetação campestre de aproximadamente 100 ha sob pastejo ovino e

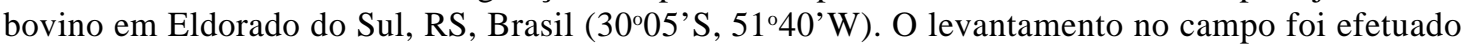
em 138 unidades amostrais de $0,5 \times 0,5 \mathrm{~m}$ localizadas sistematicamente ao longo de gradientes de relevo. As unidades amostrais foram dispostas em conjuntos de 3 quadros contíguos, que foram agrupados para análise, formando 46 quadros de $1,5 \times 0,5 \mathrm{~m}$, definindo, desta forma, duas escalas de observação. A descrição da vegetação envolveu o registro da presença e a estimativa visual da abundânciacobertura das espécies em cada quadro. Foram registradas 148 espécies pertinentes a 30 famílias. As condições ambientais em cada local foram descritas por 30 variáveis relacionadas a propriedades químicas e físicas do solo, inclinação, exposição e posição no relevo. A análise dos dados empregou análise de agrupamentos, avaliação de nitidez de grupos, ordenação, avaliação da significância de eixos de ordenação, medidas de congruência e testes de aleatorização. Os resultados obtidos na análise estatística na escala de 46 quadros confirmaram aqueles encontrados para a escala de 138 quadros. Os padrões 
da vegetação na área de estudo estão relacionados à posição no relevo e a outros fatores associados, tais como umidade do solo. Dois grupos nítidos de comunidades campestres foram detectados, um ocorrendo nas encostas e outro ocorrendo nas baixadas úmidas.

Palavras-chave: vegetação campestre, padrões de distribuição espacial, fatores ambientais, escala, análise estatística.

\section{INTRODUCTION}

Natural grassland vegetation known as "Campos" presently covers almost half of the territory of the state of Rio Grande do Sul in Brazil. Between 1970 and 1996 about one-third of the area formerly covered by natural grassland was transformed into other land uses, mainly for crop cultivation (IBGE, 1996). On the one hand this drastic land use changed points to a failure in the Brazilian legislation in protecting native grassland at the same level as forest areas are now protected. On the other hand, with such territory extent and increasing natural habitat destruction, the search for knowledge about vegetation structure and composition in the "Campos" could help to find ways for their protection and sustainable use.

The study of plant communities is essentially comparative. The physiognomy of a vegetation stand is the result of its composition in terms of plant species or types. Spatial and temporal variation in the arrangement of plant community components may be perceived by means of a classification of the communities into types. The accepted operational definition of a plant community is a unit with arbitrary limits set by the researcher and containing plant organisms (Palmer \& White, 1994). The same authors also point out that the existence of integration or interaction among the components should not be a condition to call such unit as community. Instead, whether and at which degree the components interact may be part of the study objectives. Other authors also gave important contributions to this conceptual discussion (Keddy, 1993; Wilson \& Chiarucci, 2000). Furthermore, the distribution of plants in space and time is related to or dependent on other biotic and abiotic factors (Pillar et al., 1992; Pillar \& Boldrini, 1996).

The convolution of biotic and abiotic interactions gives rise to non-random arrangements of plant organisms forming a heterogeneous and complex structure (Orlóci, 1993). Indeed, it is a fact that plant communities with similar composition tend to be found repeatedly in a given study area, revealing patterns which can be related to site factors (Kershaw, 1973; Moloney, 1993; Orlóci, 1993; Boldrini \& Eggers, 1997; Crawley, 1997). It is likely that only one factor cannot be accepted as the cause of a given plant distribution, for there are many other interacting factors (Whittaker, 1967). Gould (1991), criticizing the use of factorial analysis in IQ tests, warned against the temptation of reifying an abstraction, that is, thinking that there is something real underlying a complex of highly correlated variables. This temptation should be avoided since it may not correspond to a truth in nature. Yet, it is possible, based on survey data, to search for critical factors related to community patterns. Whether they cause or not the patterns will define hypothesis that should be further evaluated, in a process of successive approximation (Orlóci, 1993).

In the study of vegetation patterns, therefore, the sampling units (the communities in our sense) are cross sections of a continuum and are set by the investigator, which makes the sampling more complicated than when dealing with individuals. Furthermore, due to non-random arrangements, the scale (size of the sampling unit) matters, affecting the perception of patterns (Pillar, 2001). The decisions in defining the design to sample plant communities refer to the sampling unit size, number and method of location. These should be dependent on the context and objectives (Kenkel et al., 1989), therefore the conclusions are affected by the sampling design (Juhász-Nagy \& Podani, 1983; Goedickemeier et al., 1997).

Owing to the fact plant communities are complex, the analysis of their data demands the use of multivariate techniques in order to reveal patterns that may not be evident by simple inspection of the data (Digby \& Kempton, 1987; Orlóci, 1978; Pielou, 1984; Podani, 1994; Pillar, 1999a, b; Pillar \& Orlóci, 1996). Multivariate exploratory analysis may involve clustering techniques to allow the classification of units into types, or ordination to reveal the most important trends of variation in the set of communities, which are then more easily visualized and 
interpreted in terms of other variables. Moreover, most of the relations and connections are expressed in a non-linear way (Capra, 1997; Franceschi \& Prado, 1989; Orlóci, 1993; Pielou, 1984; Podani, 1994; van der Maarel, 1980). In addition, since the scale matters, the study of plant communities should contemplate different sampling unit sizes (GreigSmith, 1952; Levin, 1992; Podani et al., 1993). The sizes may vary from the smaller sizes covering a vegetation patch to larger ones involving landscape units. The use of contiguous sampling units allows the definition a posteriori of larger units in the data analysis.

The description of plant communities delimited by permanent quadrats located on environmental gradients, more specifically relief gradients, is one of the ways to study the processes and factors involved in the spatial distribution of plants and plant communities, which defines the vegetation's physiognomy.

In this paper the aim is to identify plant community patterns and relate them to environmental variables in natural grassland (Campos) located in the research station of the Federal University of Rio Grande do Sul (EEA/UFRGS) in Eldorado do Sul, RS, Brazil. We take into account two scales of observation and evaluate hypothesis about relevant environmental factors related to the community patterns.

\section{STUDY AREA}

The survey was carried out in approximately 100 ha of grazed "Campos" (natural grassland) in the EEA/UFRGS, located at $30^{\circ} 05^{\prime} \mathrm{S}, 51^{\circ} 40^{\prime} \mathrm{W}$, in Eldorado do Sul, RS, Brazil. The altitude in the study area is between 20 and $70 \mathrm{~m}$. The climate is humid subtropical, classified as $C f a$ in Köppen's classification, which is the predominant type in the lower altitudes in the south of Brazil (Moreno, 1961; Trewartha \& Horn, 1980). Extensive alluvial plains and smoothly undulated hills characterize the relief, with more or less humid depressions and valleys (Pillar \& Boldrini, 1996; Boldrini, 1997). The soils on the hills are mostly red dystrophic argisols and planosols on the lowlands (Mello et al., 1966; Embrapa, 1999).

A preliminary assessment of the physiognomy and floristic composition indicated that the vegetation is a mixture of short and tall grasses, interstitial short herbs and short to tall shrubs. The area was under cattle and sheep grazing, with patches intensively grazed mostly covered by Paspalum spp. and Axonopus affinis interspersed by ungrazed patches mostly covered by unpalatable plants of Eryngium horridum, Baccharis trimera and tall grasses such as Aristida jubata and Andropogon lateralis. The grazed patches on convex slopes show more bare soil than on the concave slopes. At the upper convex slopes the soil is dryer and the vegetation is mainly composed of Paspalum notatum, Aristida jubata, Aristida laevis, Piptochaetium montevidense, Eryngium ciliatum and Eryngium horridum. On the moist lower concave slopes the presence of Andropogon lateralis and Baccharis trimera is more common. On the wet lowland extreme environment the most frequently species are Eleocharis maculosa, Panicum sabulorum, Paspalum pumilum and Centella asiatica. Therefore, we conjectured the existence of three community types is conjectured, which are mostly related to relief position. More details on the study area can be found in Focht (2001).

\section{METHODS}

For the sampling we used 18 transects, located preferentially on relief gradients from the top of the hills in direction of the lowlands, taking into account different slopes and exposures. Guided by the transects 138 permanent quadrats of $0.5 \times 0.5 \mathrm{~m}$ (henceforth denominated small quadrats) were marked, grouped in sets of three contiguous quadrats, thus forming 46 quadrats of $0.5 \times 1.5 \mathrm{~m}$ (henceforth denominated large quadrats). In this way two study scales could be considered. The quadrats were located on three positions of the transects (upper, mid slope and lower) aiming at visually perceived homogeneous sites. The quadrats on the lower positions were not necessarily on the lowland wet sites.

The plant community composition in each $0.5 \mathrm{x}$ $0.5 \mathrm{~m}$ quadrat was described in January-February 2000 by recording the species list and visual estimation of species cover-abundance using the BraunBlanquet (1964) scale, modified by Mueller-Dombois \& Ellenberg (1974). Species identity was determined as much as possible in the field. When not possible plants of the same morph species were collected in the proximity of the quadrat for proper identification with the help of bibliography and specialists. 
When the species identity of an individual plant could not be determined either due to the lack of reproductive parts or knowledge about the taxonomic group, it was identified at the genus level.

The soil around each large quadrat of $1.5 \mathrm{x}$ $0.5 \mathrm{~m}$ was sampled in May 2000. The soil was analyzed by standard methods (Tedesco et al., $1995)$ for the following descriptors: \% of clay, $\%$ of organic matter, $\mathrm{pH}$ and exchangeable contents of $\mathrm{P}, \mathrm{K}, \mathrm{Al}, \mathrm{Ca}, \mathrm{Mg}, \mathrm{S}, \mathrm{Zn}, \mathrm{Cu}, \mathrm{B}$ and $\mathrm{Mn}$, cation exchange capacity (CEC) and derived indexes of saturation of CEC with aluminum and hydrogen, saturation of CEC with bases, saturation of CEC with $\mathrm{Al}, \mathrm{Ca} / \mathrm{Mg}$ ratio, $\mathrm{Ca} / \mathrm{K}$ ratio and $\mathrm{Mg} / \mathrm{K}$ ratio. Soil moisture regime at the quadrat's site was evaluated by visual and tactile observation using the following scale: 1 : moist only after a rain, 2 : dry only in short drought periods, and 3: always moist. Bare soil and cover by litter material on the soil were visually estimated in each small quadrat using the Braun-Blanquet scale already mentioned. The relief position of the quadrat was recorded using a semi-quantitative scale: 1 (top and convex slope), 2 (concave slope), and 3 (lowland). The average vegetative stand height and the average thickness of the litter layer on the soil were also estimated for each small quadrat. Potential solar radiation on the quadrat was estimated for each season on the basis of its slope and exposure and radiation data from the meteorological station at EEA/UFRGS in the year 1999, according to the methodology described in Forseth \& Norman (1983).

The data on community composition were initially arranged in a matrix of species by communities (small quadrats). The cover-abundance symbols of the Braun-Blanquet scale (r, +, 1, 2, 3, 4 and 5) were replaced by values according to van der Maarel (1979): 1, 2, 3, 5, 7, 8, and 9, respectively. The data analysis was performed separately at the two scales of quadrat size (small and large). The community composition data matrix for the large quadrats was analytically found by computing the average cover-abundance value for each species based on the three small contiguous quadrats nested in the large quadrat. The same procedure was used to find average values for environmental variables in the large quadrats when the variable was evaluated only in the small quadrats.
The software SYNCSA was used for multivariate analysis, involving data preparation, ordination of quadrats, cluster analysis of quadrats, evaluation of congruence with other environmental variables and graphical output (Pillar \& Orlóci, 1993; Pillar, 2000a). The software MULTIV (Pillar, 1997; Pillar, 2000b) was used for testing the significance of ordination axes, sharpness of groups in cluster analysis and for randomization testing in multivariate analysis of variance. The objective of the analyses was to detect vegetation patterns and to relate them to other environmental variables. The multivariate analyses were based on a matrix of pair-wise chord distances of quadrats. Chord distance is Euclidean distance using data standardized by dividing each datum by the corresponding squared root of the sum of squared values within the quadrat. Cluster analysis followed the sum of squares clustering criterion (Podani, 1994). The sharpness of quadrat groups defined in cluster analysis was tested according to Pillar (1999b). For ordination the method of principal coordinates analysis (Podani, 1994) was used. For testing the significance of ordination axes the method described by Pillar (1999a) was followed. Ordination results were graphically represented in two-dimension scatter diagrams: the dimensions being the most relevant ordination axes and the points the quadrats (communities), allowing visualizing the patterns.

To find out which environmental variables were the most relevant for explaining the community patterns the congruence among community and environmental variation was evaluated. Congruence was computed as the matrix correlation between community dissimilarities based on the main ordination axis and the dissimilarities of the same sites but based on environmental variables. For this the stepwise algorithm described in Pillar \& Orlóci (1993) was followed, which starts by choosing the variable that when used alone maximizes the correlation, then selects among the remaining variables the one that together with the first maximizes the correlation and so on until the complete set of variables is taken. To complete the analysis it was tested whether quadrat groups defined by these variables were significantly different with regard to species composition. For that multivariate analysis of variance and randomization testing were used following the method described in Pillar \& Orlóci (1996). The probabilities as produced were used 
to statistically test for the association between community composition (in the large quadrats) and environmental conditions.

\section{RESULTS AND DISCUSSION}

The survey carried out in the 138 small quadrats allowed to find 148 species belonging to 30 families (Table 1). By cluster analysis two groups of quadrats were identified with this data set. The groups were considered as two distinct community types, as indicated by the test for group sharpness (Pillar, 1999b). Also two distinct community types were identified by cluster analysis with the data from the large quadrats. The communities (quadrats) belonging to the same group tend to be more similar than communities belonging to different groups. At this clustering level there was no evident effect of the observation scale, since the small quadrats into the large ones by nesting showed the classification produced was nearly the same. Henceforth we will give emphasis to the results with the large quadrats. More than two community groups could be defined on the basis of the cluster analyses but the groups would not be sharp enough in the sense that they would not be sufficiently stable to reappear if the same sampling universe were resampled (Pillar, $1999 \mathrm{~b})$. Details on the results of the cluster analyses can be found in Focht (2001).

Table 2 shows the average values for the environmental variables in each group formed with the large quadrats on the basis of floristic data. The inspection of the table indicates which variables are more associated to the community types: relief position and associated variables such as soil moisture, clay, $\mathrm{K}$ and $\mathrm{Ca}$ content.

The conjectured existence of three distinct community types was not confirmed by data analysis, since only two sharp groups were defined. Two community types are clearly separated in two relief positions: Quadrats belonging to group 1 are located on the upper convex slopes and lower concave slopes, while quadrats belonging to group 2 are on the wet lowland. The species found in the survey were grouped according to the percentage of presence in each community type. In this way it could be identified which species are characteristic of each community type and which are more generalist ones (Table 1). In Table 1 the first species group contains the species that occur in more than $50 \%$ of the quadrats in both community types, which means that they are the species with the greatest ecological plasticity, considering that they occur in a wide environmental range. The second species group contains the species present in more than 50\% of the quadrats belonging to community type 1 and thus is characteristic of dryer sites. The species in the third group occur in more than $50 \%$ of the quadrats in community type 2 and are indicators of wet lowland conditions. The fourth species group does not have clear preferences since the species are present in less than $50 \%$ of the quadrats in any of the community types.

The ordination results reveal the spatial distribution pattern of the communities. In Fig. 1 the quadrats are arranged solely according to the main ordination axes generated from the species composition. The horseshoe-like arrangement of the communities in the ordination scatter diagram is an indication of non-linear responses of species, not an artifact that would require some kind of detrending (Podani, 1994). It could be seen that this arrangement matches very well with the soil moisture gradient (Fig. 1A), and soil moisture is mostly a consequence of relief position. Based on the species mostly correlated with the ordination axes the gradient could be interpreted in terms of species composition. $E$. horridum is typical of communities on dryer sites (soil moisture class 1) located on convex slopes (upper left corner of the diagram). As we move from left to right on the diagram along the moisture gradient there is a gradual substitution of species. Andropogon lateralis is typical of communities on moist sites (soil moisture class 2) on lower concave slopes. Panicum sabulorum, Paspalum pumilum, Centella asiatica and Eleocharis maculosa are typical of the wet lowland areas (soil moisture class 3).

The ordination of the communities reflects also the results of the cluster analysis, since both community types are clearly separated (Fig. 1B). Based on the ordination diagram and on the fact that only two sharply defined groups were found in cluster analysis it could be concluded that within community type 1 there is a gradual variation in the species composition from the convex to concave relief positions on the slopes, while species substitution is abrupt from the lower concave slopes to the wet lowlands. 
TABLE 1

List of species found in the survey of $461.5 \times 0.5 \mathrm{~m}$ quadrats on natural grassland in Eldorado do Sul, RS, Brazil. Percentage of presence and average cover-abundance values (van der Maarel scale) in two community types are indicated.

\begin{tabular}{|c|c|c|c|c|c|c|}
\hline \multirow[b]{2}{*}{ Species } & \multicolumn{3}{|c|}{$\begin{array}{l}\text { Presence }(\%) \text { in } \\
\text { community types }\end{array}$} & \multicolumn{3}{|c|}{$\begin{array}{c}\text { Average cover-abundance } \\
\text { when present }\end{array}$} \\
\hline & 1 & 2 & $1+2$ & 1 & 2 & $1+2$ \\
\hline \multicolumn{7}{|c|}{ Species with presence $>\mathbf{5 0} \%$ in both community types } \\
\hline Paspalum notatum & 97.0 & 61.5 & 87.0 & 4.1 & 3.5 & 4.0 \\
\hline Andropogon lateralis & 75.8 & 100 & 82.6 & 4.0 & 4.2 & 4.0 \\
\hline Baccharis trimera & 72.7 & 76.9 & 73.9 & 1.9 & 0.9 & 1.6 \\
\hline Rhynchospora microcarpa & 51.5 & 92.3 & 63.0 & 1.6 & 2.5 & 2.0 \\
\hline \multicolumn{7}{|c|}{ Species with presence $>\mathbf{5 0 \%}$ only in community type 1} \\
\hline Oxalis corniculata & 97.0 & 30.8 & 78.3 & 2.0 & 0.7 & 1.1 \\
\hline Piptochaetium montevidense & 93.9 & 38.5 & 78.3 & 2.6 & 1.3 & 1.1 \\
\hline Eryngium horridum & 78.8 & 7.7 & 58.7 & 3.8 & 1.7 & 3.7 \\
\hline Dichondra sericea & 75.8 & 15.4 & 58.7 & 1.6 & 0.7 & 1.5 \\
\hline Desmodium incanum & 72.7 & 23.1 & 58.7 & 1.4 & 1.6 & 1.4 \\
\hline Ruellia morongii & 66.7 & 30.8 & 56.5 & 1.2 & 1.1 & 1.2 \\
\hline Evolvolus sericeus & 66.7 & 0 & 47.8 & 1.2 & 0 & 1.2 \\
\hline Paspalum paucifolium & 63.6 & 7.7 & 47.8 & 1.6 & 0.7 & 1.6 \\
\hline Chevreulia sarmentosa & 60.6 & 23.1 & 50.0 & 1.1 & 0.9 & 1.1 \\
\hline Stylosanthes leiocarpa & 57.6 & 46.2 & 54.3 & 1.2 & 1.1 & 1.3 \\
\hline Aristida jubata & 54.5 & 7.7 & 41.3 & 2.9 & 1.7 & 2.8 \\
\hline Aristida laevis & 51.5 & 15.4 & 41.3 & 2.2 & 1.3 & 2.1 \\
\hline \multicolumn{7}{|c|}{ Species with presence $>\mathbf{5 0} \%$ only in community type 2} \\
\hline Paspalum pumilum & 6.1 & 100 & 32.6 & 1.0 & 3.4 & 3.1 \\
\hline Centella asiatica & 18.2 & 92.3 & 39.1 & 1.7 & 3.2 & 2.7 \\
\hline Diodia sp. & 24.2 & 84.6 & 28.3 & 0.9 & 3.9 & 1.0 \\
\hline Eleocharis maculosa & 3.0 & 84.6 & 26.1 & 2.7 & 3.9 & 3.8 \\
\hline Panicum sabulorum & 24.2 & 76.9 & 39.1 & 1.3 & 1.3 & 1.3 \\
\hline Tibouchina gracilis & 12.1 & 69.2 & 28.3 & 1.3 & 1.1 & 1.2 \\
\hline Desmodium adscendens & 30.3 & 69.2 & 41.3 & 1.4 & 1.0 & 1.2 \\
\hline Axonopus affinis & 27.3 & 61.5 & 37.0 & 2.1 & 1.7 & 1.9 \\
\hline \multicolumn{7}{|c|}{ Other species } \\
\hline Vernonia nudiflora & 42.4 & 38.5 & 41.3 & 1.6 & 1.0 & 1.4 \\
\hline Hypoxis decumbens & 42.4 & 38.5 & 41.3 & 1.1 & 0.7 & 1.1 \\
\hline Andropogon selloanus & 45.5 & 30.8 & 39.1 & 1.7 & 1.1 & 1.6 \\
\hline Chevreulia acuminata & 42.4 & 30.8 & 37.0 & 0.9 & 0.7 & 0.9 \\
\hline Oxalis corymbosa & 45.5 & 23.1 & 37.0 & 0.8 & 3.4 & 0.7 \\
\hline Richardia sp. & 48.5 & 0 & 34.8 & 1.4 & 0 & 1.4 \\
\hline
\end{tabular}


TABLE 1 (continued.)

\begin{tabular}{|c|c|c|c|c|c|c|}
\hline \multirow[b]{2}{*}{ Species } & \multicolumn{3}{|c|}{$\begin{array}{l}\text { Presence }(\%) \text { in } \\
\text { community types }\end{array}$} & \multicolumn{3}{|c|}{$\begin{array}{l}\text { Average cover-abundance } \\
\text { when present }\end{array}$} \\
\hline & 1 & 2 & $1+2$ & 1 & 2 & $1+2$ \\
\hline \multicolumn{7}{|c|}{ Other species } \\
\hline Euphorbia selloi & 48.5 & 0 & 34.8 & 0.8 & 0 & 0.8 \\
\hline Polygala pumila & 42.4 & 15.4 & 34.8 & 0.8 & 0.3 & 0.7 \\
\hline Aspilia montevidense & 42.4 & 7.7 & 32.6 & 1.2 & 0.7 & 1.2 \\
\hline Clitoria nana & 45.5 & 0 & 32.6 & 0.8 & 0 & 0.8 \\
\hline Borreria eryngioides & 45.5 & 0 & 32.6 & 0.7 & 0 & 0.7 \\
\hline Richardia grandiflora & 36.4 & 0 & 26.1 & 0.8 & 0 & 0.8 \\
\hline Eryngium ciliatum & 33.3 & 23.1 & 23.9 & 0.9 & 1.0 & 1.4 \\
\hline Aeschynomene falcata & 33.3 & 0 & 23.9 & 0.9 & 0 & 0.9 \\
\hline Sporobolus indicus & 30.3 & 15.4 & 21.7 & 1.4 & 1.3 & 1.1 \\
\hline Relbunium richardianum & 27.3 & 7.7 & 21.7 & 2.1 & 0.7 & 0.5 \\
\hline Orthopappus angustifolius & 27.3 & 0 & 19.6 & 0.8 & 0 & 0.8 \\
\hline Cliococca selaginoides & 27.3 & 0 & 19.6 & 0.7 & 0 & 0.7 \\
\hline Stylosanthes montevidensis & 27.3 & 7.7 & 19.6 & 0.4 & 0.7 & 0.6 \\
\hline Peltodon longipes & 24.2 & 7.7 & 17.4 & 1.6 & 1.3 & 1.0 \\
\hline Richardia humistrata & 24.2 & 0 & 17.4 & 1.0 & 0 & 1.0 \\
\hline Pfaffia tuberosa & 24.2 & 0 & 17.4 & 0.9 & 0 & 0.8 \\
\hline Cyperus lanceolatus & 24.2 & 15.4 & 15.2 & 0.8 & 1.8 & 1.2 \\
\hline Scleria hirtella & 24.2 & 15.4 & 15.2 & 0.6 & 1.3 & 1.2 \\
\hline Polygala sp. & 21.2 & 0 & 15.2 & 1.0 & 0 & 1.0 \\
\hline Cuphea sp. & 21.2 & 0 & 15.2 & 0.7 & 0 & 0.6 \\
\hline Borreria capitata & 21.2 & 15.4 & 13.0 & 0.6 & 1.0 & 1.2 \\
\hline Lucilia nitens & 18.2 & 0 & 13.0 & 1.7 & 0 & 1.0 \\
\hline Fimbristylis dichotoma & 18.2 & 15.4 & 13.0 & 0.8 & 0.7 & 0.9 \\
\hline Chaptalia exscapa & 18.2 & 0 & 13.0 & 0.6 & 0 & 0.6 \\
\hline Desmanthus depressus & 15.2 & 0 & 13.0 & 1.8 & 0 & 0.6 \\
\hline Schizachyrium tenerum & 15.2 & 7.7 & 10.9 & 1.2 & 3.0 & 2.5 \\
\hline Baccharis cylindrica & 15.2 & 0 & 10.9 & 1.0 & 0 & 1.8 \\
\hline Conyza chilensis & 15.2 & 15.4 & 10.9 & 0.9 & 1.2 & 1.1 \\
\hline Sacciolepis myuros & 15.2 & 15.4 & 10.9 & 0.7 & 1.0 & 1.1 \\
\hline Pratia hederacea & 12.1 & 15.4 & 10.9 & 2.3 & 1.2 & 0.9 \\
\hline Richardia stellaris & 12.1 & 0 & 10.9 & 1.5 & 0 & 0.7 \\
\hline Oxalis sp. & 12.1 & 0 & 10.9 & 1.3 & 0 & 0.7 \\
\hline Eragrostis neesii & 12.1 & 0 & 8.7 & 1.2 & 0 & 1.5 \\
\hline Rhynchospora tenuis & 12.1 & 23.1 & 8.7 & 1.1 & 1.6 & 1.3 \\
\hline Eragrostis bahiensis & 12.1 & 15.4 & 8.7 & 0.9 & 1.2 & 0.9 \\
\hline
\end{tabular}


TABLE 1 (continued.)

\begin{tabular}{|c|c|c|c|c|c|c|}
\hline \multirow[b]{2}{*}{ Species } & \multicolumn{3}{|c|}{$\begin{array}{l}\text { Presence }(\%) \text { in } \\
\text { community types }\end{array}$} & \multicolumn{3}{|c|}{$\begin{array}{l}\text { Average cover-abundance } \\
\text { when present }\end{array}$} \\
\hline & 1 & 2 & $1+2$ & 1 & 2 & $1+2$ \\
\hline \multicolumn{7}{|c|}{ Other species } \\
\hline Cuphea glutinosa & 12.1 & 0 & 8.7 & 0.8 & 0 & 0.9 \\
\hline Panicum decipiens & 12.1 & 0 & 8.7 & 0.7 & 0 & 0.8 \\
\hline Fimbristylis diphylla & 12.1 & 15.4 & 8.7 & 0.7 & 1.0 & 0.8 \\
\hline Ruellia sp. & 12.1 & 7.7 & 8.7 & 0.7 & 0.3 & 0.8 \\
\hline Sida rhombifolia & 12.1 & 0 & 8.7 & 0.7 & 0 & 0.7 \\
\hline Justicia sp. & 12.1 & 0 & 8.7 & 0.6 & 0 & 0.7 \\
\hline Waltheria douradinha & 12.1 & 0 & 8.7 & 0.3 & 0 & 0.7 \\
\hline Zornia sp. & 12.1 & 0 & 8.7 & 0.3 & 0 & 0.3 \\
\hline Paspalum sp. & 9.1 & 23.1 & 6.5 & 1.6 & 1.9 & 1.9 \\
\hline Galianthe fastigiata & 9.1 & 0 & 6.5 & 1.1 & 0 & 1.6 \\
\hline Bulbostylis juncoides & 9.1 & 7.7 & 6.5 & 1.1 & 0.7 & 1.3 \\
\hline Cyperus tener & 9.1 & 7.7 & 6.5 & 0.9 & 1.7 & 1.2 \\
\hline Glandularia sp. & 9.1 & 0 & 6.5 & 0.9 & 0 & 1.1 \\
\hline Schizachyrium microstachyum & 9.1 & 15.4 & 6.5 & 0.8 & 0.7 & 1.0 \\
\hline Sida sp. & 9.1 & 7.7 & 6.5 & 0.7 & 0.7 & 0.9 \\
\hline Paspalum plicatulum & 9.1 & 0 & 6.5 & 0.7 & 0 & 0.8 \\
\hline Setaria geniculata & 9.1 & 0 & 6.5 & 0.7 & 0 & 0.7 \\
\hline Pterocaulon sp. & 9.1 & 0 & 6.5 & 0.6 & 0 & 0.7 \\
\hline Pterocaulon rugosum & 9.1 & 0 & 6.5 & 0.4 & 0 & 0.6 \\
\hline Sisyrinchium sp. & 6.1 & 7.7 & 6.5 & 1.7 & 0.7 & 0.6 \\
\hline Verbena lindmanii & 6.1 & 0 & 6.5 & 1.3 & 0 & 0.4 \\
\hline Tibouchina asperior & 0 & 15.4 & 4.3 & 0 & 2.0 & 2.0 \\
\hline Drymaria cordata & 6.1 & 0 & 4.3 & 1.3 & 0 & 1.3 \\
\hline Paspalum nicorae & 6.1 & 0 & 4.3 & 1.3 & 0 & 1.0 \\
\hline Crotalaria tweediana & 6.1 & 0 & 4.3 & 1.0 & 0 & 1.0 \\
\hline Mecardonia sp. & 6.1 & 0 & 4.3 & 1.0 & 0 & 0.8 \\
\hline Borreria verticillata & 6.1 & 0 & 4.3 & 1.0 & 0 & 0.8 \\
\hline Andropogon macrothrix & 6.1 & 7.7 & 4.3 & 1.0 & 0.7 & 0.8 \\
\hline Commelina sp. & 6.1 & 0 & 4.3 & 1.0 & 0 & 0.8 \\
\hline Vernonia flexuosa & 6.1 & 0 & 4.3 & 0.8 & 0 & 0.7 \\
\hline Brachiaria plantaginea & 6.1 & 0 & 4.3 & 0.8 & 0 & 0.7 \\
\hline Baccharis sp. & 6.1 & 0 & 4.3 & 0.7 & 0 & 0.7 \\
\hline Senecio selloi & 6.1 & 0 & 4.3 & 0.7 & 0 & 0.7 \\
\hline Fimbristylis cf autumnalis & 0 & 15.4 & 4.3 & 0 & 0.5 & 0.5 \\
\hline Xyris jupicai & 6.1 & 7.7 & 4.3 & 0.3 & 0.3 & 0.3 \\
\hline Hypogynium virgatum & 0 & 7.7 & 2.2 & 0 & 4.7 & 4.7 \\
\hline
\end{tabular}


TABLE 1 (continued.)

\begin{tabular}{|c|c|c|c|c|c|c|}
\hline \multirow[b]{2}{*}{ Species } & \multicolumn{3}{|c|}{$\begin{array}{l}\text { Presence }(\%) \text { in } \\
\text { community types }\end{array}$} & \multicolumn{3}{|c|}{$\begin{array}{l}\text { Average cover-abundance } \\
\text { when present }\end{array}$} \\
\hline & 1 & 2 & $1+2$ & 1 & 2 & $1+2$ \\
\hline \multicolumn{7}{|c|}{ Other species } \\
\hline Saccharum angustifolium & 3.0 & 0 & 2.2 & 3.3 & 0 & 3.3 \\
\hline Rhynchospora uleana & 0 & 7.7 & 2.2 & 0 & 2.0 & 2.0 \\
\hline Senecio oxyphyllus & 0 & 7.7 & 2.2 & 0 & 1.7 & 1.7 \\
\hline Aristida filifolia & 3.0 & 0 & 2.2 & 3.3 & 0 & 1.0 \\
\hline Eryngium elegans & 3.0 & 0 & 2.2 & 3.3 & 0 & 1.0 \\
\hline Briza sp. & 0 & 7.7 & 2.2 & 0 & 1.0 & 1.0 \\
\hline Psidium luridum & 3.0 & 0 & 2.2 & 0.7 & 0 & 0.7 \\
\hline Ludwigia sp. & 3.0 & 0 & 2.2 & 0.7 & 0 & 0.7 \\
\hline Chaptalia runcinata & 3.0 & 0 & 2.2 & 0.7 & 0 & 0.7 \\
\hline Abildgeardia sp. & 3.0 & 0 & 2.2 & 0.7 & 0 & 0.7 \\
\hline Eryngium sanguisorba & 0 & 7.7 & 2.2 & 0 & 0.7 & 0.7 \\
\hline Lippia $\mathrm{sp}$. & 3.0 & 0 & 2.2 & 0.7 & 0 & 0.7 \\
\hline Elephantopus mollis & 0 & 7.7 & 2.2 & 0 & 0.7 & 0.7 \\
\hline Richardia brasiliensis & 3.0 & 0 & 2.2 & 0.7 & 0 & 0.7 \\
\hline Solidago sp. & 3.0 & 0 & 2.2 & 0.7 & 0 & 0.7 \\
\hline Campomanesia aurea & 3.0 & 0 & 2.2 & 0.7 & 0 & 0.7 \\
\hline Phyllanthus sp. & 0 & 7.7 & 2.2 & 0 & 0.7 & 0.7 \\
\hline Macrosiphonia petraea & 3.0 & 0 & 2.2 & 0.7 & 0 & 0.7 \\
\hline Briza cf poaemorpha & 3.0 & 0 & 2.2 & 0.7 & 0 & 0.7 \\
\hline Stevia $\mathrm{sp}$. & 3.0 & 0 & 2.2 & 0.7 & 0 & 0.7 \\
\hline Bulbostylis consanguinea & 3.0 & 0 & 2.2 & 0.7 & 0 & 0.3 \\
\hline Gamochaeta filaginea & 0 & 7.7 & 2.2 & 0 & 0.3 & 0.3 \\
\hline Krapovickasia macrodon & 3.0 & 0 & 2.2 & 0.3 & 0 & 0.3 \\
\hline
\end{tabular}

The test evaluating the significance of the ordination axes indicated that only axis 1 was significant in both ordinations with large and small quadrats. Axis 2 and the other axes were not significant, that is, the ordination on these axes was not distinguishable from an ordination obtained if the variables were completely uncorrelated (Pillar, 1999a).

The species richness in community type 1 is higher than in community type 2 , which becomes evident by inspection of Table 1 . The possible cause of this fact is that the environmental conditions on the slopes may present greater seasonal fluctuation than those in the wet lowland sites, despite the variation in the moisture conditions. If this is true, the assertion by Levin (1992) is confirmed, in the sense that site variation gives opportunity to species that otherwise would be eliminated by competition in a constant environment, causing a greater diversity at intermediate levels of disturbance. For Crawley (1997), soil surface disturbance and destruction of established plants can offer small gaps to recruitment, which cause the community to be invaded by new species, increasing species richness. Indeed, type 1 communities are located on sites with barer soil (Table 2). 
TABLE 2

Average values for the environmental variables in both grassland community types (Group 1, Group 2) in Eldorado do Sul, RS, Brazil. The types were found by cluster analysis with species composition data.

\begin{tabular}{|c|c|c|c|c|}
\hline Variable & Labels & Unit & Group 1 & Group 2 \\
\hline Stand height & ave & $\mathrm{cm}$ & 11.98 & 10.50 \\
\hline Litter cover & com & $1-9$ class & 6.02 & 5.00 \\
\hline Litter thickness & alm & $\mathrm{cm}$ & 0.98 & 0.73 \\
\hline Bare soil & sod & 1-9 class & 2.44 & 1.38 \\
\hline Relief position of the quadrat & poq & $1-3$ class & 1.76 & 3.00 \\
\hline Soil moisture regime & ums & $1-3$ class & 1.21 & 2.77 \\
\hline Clay & $\arg$ & $\%$ & 20.97 & 13.85 \\
\hline $\mathrm{pH}$ & $\mathrm{ph}$ & - & 4.83 & 4.57 \\
\hline $\mathrm{P}$ & $\mathrm{p}$ & mg. $\mathrm{L}^{-1}$ & 3.13 & 3.13 \\
\hline $\mathrm{K}$ & $\mathrm{k}$ & $\mathrm{mg} \cdot \mathrm{L}^{-1}$ & 170.33 & 103.08 \\
\hline Organic matter & mo & $\%$ & 3.76 & 4.62 \\
\hline $\mathrm{Al}^{+++}$ & alt & cmol.c. $\mathrm{L}^{-1}$ & 0.46 & 1.04 \\
\hline $\mathrm{Ca}$ & cat & cmol.c. $\mathrm{L}^{-1}$ & 2.05 & 1.43 \\
\hline $\mathrm{Mg}$ & mgt & cmol c. $\mathrm{L}^{-1}$ & 1.38 & 0.75 \\
\hline $\mathrm{Al}^{+++}$plus $\mathrm{H}^{+}$ & alh & cmol.c. $\mathrm{L}^{-1}$ & 6.05 & 7.56 \\
\hline Cation exchange capacity (CEC) & cec & cmol.c. $\mathrm{L}^{-1}$ & 9.68 & 10.07 \\
\hline Saturation of CEC with bases & $\mathrm{ctb}$ & $\%$ & 37.56 & 26.77 \\
\hline Saturation of CEC with $\mathrm{Al}$ & cta & $\%$ & 5.00 & 9.33 \\
\hline $\mathrm{Ca} / \mathrm{Mg}$ ratio & cam & - & 1.66 & 2.02 \\
\hline $\mathrm{Ca} / \mathrm{K}$ ratio & cal & - & 4.91 & 5.48 \\
\hline $\mathrm{Mg} / \mathrm{K}$ ratio & mgk & - & 3.15 & 2.87 \\
\hline S & $\mathrm{s}$ & $\mathrm{mg} \cdot \mathrm{L}^{-1}$ & 9.57 & 10.64 \\
\hline $\mathrm{Zn}$ & $\mathrm{zn}$ & $\mathrm{mg} . \mathrm{L}^{-1}$ & 2.91 & 2.71 \\
\hline $\mathrm{Cu}$ & $\mathrm{cu}$ & $\mathrm{mg} \cdot \mathrm{L}^{-1}$ & 1.27 & 1.49 \\
\hline B & $\mathrm{b}$ & $\mathrm{mg} \cdot \mathrm{L}^{-1}$ & 0.67 & 0.60 \\
\hline $\mathrm{Mn}$ & $\mathrm{mn}$ & $\mathrm{mg} \cdot \mathrm{L}^{-1}$ & 40.00 & 33.54 \\
\hline Summer potential radiation & rve & $\left(\mathrm{MJ} \cdot \mathrm{m}^{-2}\right.$.day) & 27.38 & 27.43 \\
\hline Autumn potential radiation & rou & (MJ.m. ${ }^{-2}$ day) & 17.27 & 17.29 \\
\hline Winter potential radiation & rin & (MJ.m ${ }^{-2}$.day) & 9.562 & 9.569 \\
\hline Spring potential radiation & rpr & (MJ.m. ${ }^{-2}$ day) & 20.93 & 21.10 \\
\hline
\end{tabular}




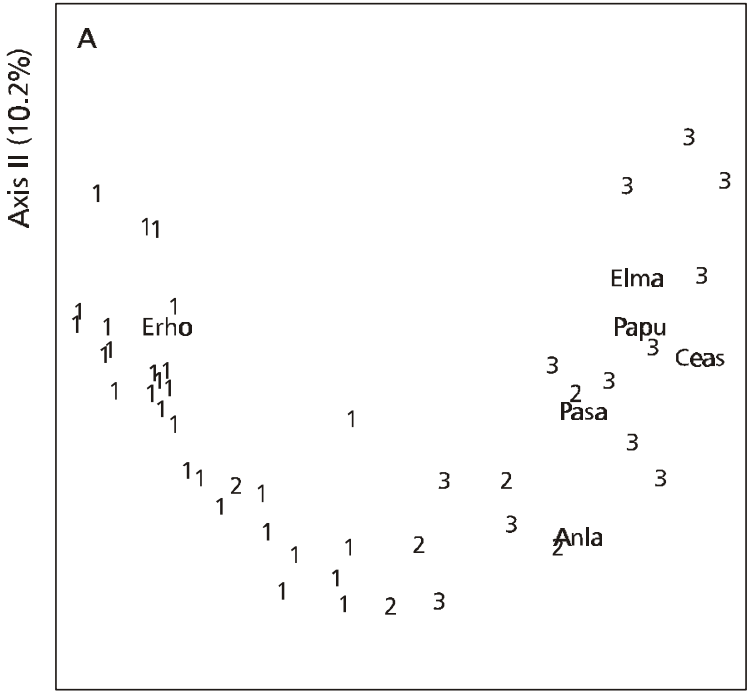

Axis I (27.2\%)

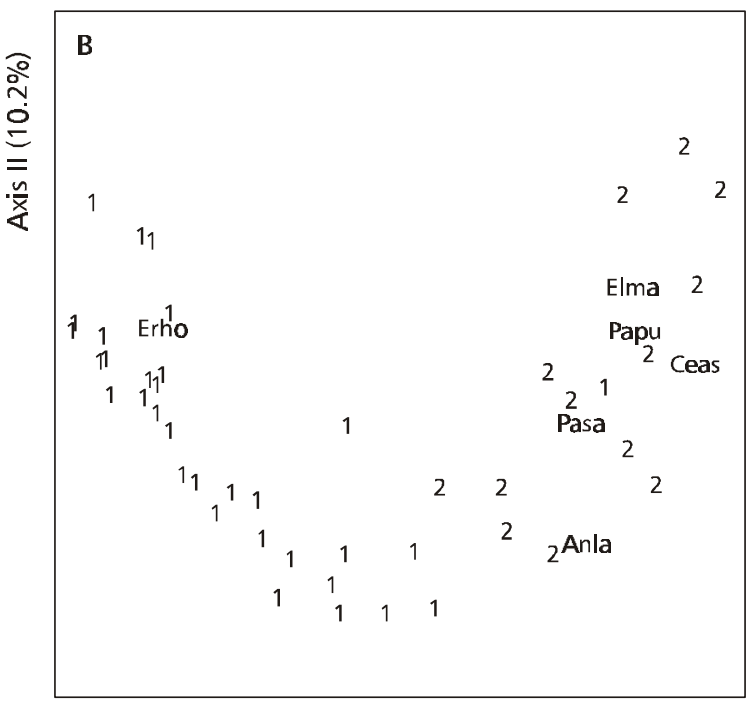

Axis I (27.2\%)

Fig. 1 - Ordination of 46 grassland communities (quadrats $1.5 \times 0.5 \mathrm{~m}$ ) in Eldorado do Sul, RS, Brazil. The scatter diagram is defined by ordination axes 1 and 2 generated by principal coordinates analysis from chord distances using the species composition data. The percentage of total variation represented by the axes is indicated. The species plotted on the diagram had a correlation $|\mathrm{r}| \geq$ 0.6 with at least one of the axes: Erho =E. horridum; Anla = A. lateralis; Pasa = P. sabulorum; Ceas = C. asiatica $;$ Papu $=$ P. pumilum; and Elma $=E$. maculosa . Diagrams A and B are identical except that in A the numbers 1-3 identify the soil moisture state of the quadrat (scale in the main text) and in B the numbers 1-2 identify the community types revealed by cluster analysis. 
The evaluation of congruence between variation in vegetation composition on the first ordination axis, since only this axis was significant, and environmental conditions indicated that soil moisture was the variable that when used alone produced maximum correlation (Fig. 2). When other variables were included the correlation became lower, however for sets with two variables it was maximum when soil moisture was combined with relief position.

Comparing both observation scales (large and small quadrats), no remarkable differences were found in the results. The analysis with the 46 large quadrats reflected the same variation found in the 138 small quadrats. This may indicate that the three small contiguous quadrats are mainly not independent, since they are very close in space, sometimes with the same individual being observed across neighboring quadrats.

The results show that the main factors related to vegetation variation in the studied grassland are linked to relief position. Actually, variables such as soil moisture regime, soil cationic exchange capacity, $\mathrm{pH}$ and exchangeable $\mathrm{Al}$ and the soil type are clearly a consequence of relief position. These findings are supported by studies on similar grassland in the EEA/UFRGS (Pillar et al., 1992; Boldrini,
1993) and other vegetation elsewhere (Wierenga et al., 1987; Franceschi \& Prado, 1989). Grazing may be also an important factor but it was not evaluated in this study. According to Whittaker (1967), only one factor cannot be accepted as the cause of plant distribution, since there is a group of variables interacting. The network of relations linking the biotic components and abiotic factors is probably so complicate and huge that they are mathematically intractable (Gould, 1991; Orlóci, 1993). Therefore, the results of a survey will always be a simplification, but may be the best information available.

Causal relationships should not be concluded based on survey data, since the environmental variable that best explains the species composition could not be the variable that really is affecting the vegetation, but another variable related to the first one (Crawley, 1997). However, exploratory studies like this are useful since they can detect the variables with greater probability to influence the vegetation, which may help the better designing of future surveys or experiments (Feoli \& Orlóci, 1985). Despite the limitations, it is possible to say, for instance, that there is a clear separation between the behavior of Eryngium horridum, frequent on sites with dryer soil conditions and Eleocharis maculosa, typical of wet sites.
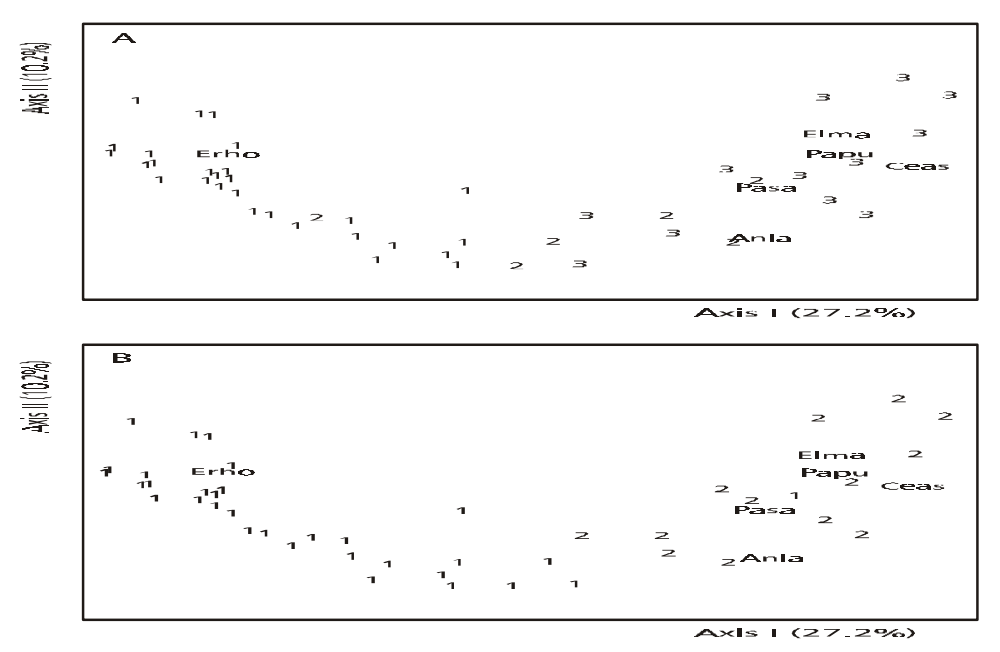

Fig. 2 - Profile of maximum congruence between vegetation variation on the first ordination axis (Fig. 1) and environmental variation given by the variables indicated on the abscissa cumulatively from left to right. Legends of the variables should be read vertically and are indicated in Table 2 . 
Using multivariate analysis of variance it was tested whether quadrat groups defined by selected environmental variables (factors) were significantly different with regard to the complete species composition (Pillar \& Orlóci, 1996). The analysis was done for each environmental variable. It was found that quadrat groups defined by soil moisture classes were significantly different $(\mathrm{p}<0.05)$. The same was found for groups defined by relief position, soil cationic exchange capacity, litter cover, soil $\mathrm{pH}$ and soil exchangeable Al. These variables were significantly related to the species composition of the communities. No significant differences in species composition were found for factors such as soil $\mathrm{P}$, stand height and winter potential radiation $(\mathrm{p}>0.05)$.

\section{CONCLUSIONS}

The vegetation patterns in the study area are associated to relief position and other related factors such as soil moisture.

Two clearly defined grassland community types were detected, one occurring on slopes and another on wet lowlands.

Both scales of observation (small and large quadrats) revealed nearly the same patterns.

Acknowledgments - This work was supported by a scholarship from CAPES received by T.F. and by a grant and fellowship received by V.P. from CNPq (Brazil). We thank Juliana Cunha for helping with the translation of the manuscript to English.

\section{REFERENCES}

BOLDRINI, I. I., 1993, Dinâmica de vegetação de uma pastagem natural sob diferentes niveis de oferta de forragem e tipos de solos, Depressão Central, RS. Tese de Doutorado, Faculdade de Agronomia, UFRGS, Porto Alegre, 262p.

BOLDRINI, I. I., 1997, Campos do Rio Grande do Sul: caracterização fisionômica e problemática ocupacional. Bol. Inst. Biocienc./UFRGS, 56: 1-39.

BOLDRINI, I. I. \& EGGERS, L., 1997, Directionally of sucession after grazing exclusion in grassland in the South of Brazil. Coenoses, 12: 63-66.

BRAUN-BLANQUET, J., 1964, Fitossociología: bases para el estudio de las comunidades vegetales (Pflanzensoziologie. Grundzüge der Vegetationskunde).Trad. 3. ed. rev. aum. Blume, Madrid, 819p.

CAPRA, F., 1997, A teia da vida. Cultrix, São Paulo, 256p.

CRAWLEY, M. J., 1997, The structure of plant communities. In: Plant ecology. 2. ed., Blackwell, Oxford.
DIGBY, P. G. N. \& KEMPTON, R. A., 1987, Multivariate analysis of ecological communities. Chapman \& Hall, London, 206p.

EMBRAPA, 1999, Classificação dos solos brasileiros. EMBRAPA, Brasília, 412p.

FEOLI, E. \& ORLÓCI, L., 1985, Species dispersion profiles of anthropogenic grasslands in the Italian Eastern Pre-Alps. Vegetatio, 60: 113-118.

FOCHT, T., 2001, Padrões espaciais em comunidades vegetais de um campo pastejado e suas relações com fatores de ambiente. Dissertação de Mestrado, Departamento de Ecologia, UFRGS, Porto Alegre, 167p.

FORSETH, I. N. \& NORMAN, J. M., 1983, Modelling of solar irradiance, leaf energy budget and canopy photosynthesis and production in a changing environment. A field and laboratory manual. Chapman \& Hall, London.

FRANCESCHI, E. A. \& PRADO, D. E., 1989, Distribution of herbaceous communities of the River Parana Valley along an elevation gradient after a catastrophic flood. Coenoses, 4: 47-53.

GOEDICKEMEIER, I., WILDI, O. \& KIENAST, F., 1997, Sampling for vegetation survey: some properties of a GISbased stratification compared to other statistical sampling methods. Coenoses, 12: 43-50.

GOULD, S. J., 1991, A falsa medida do homem. Martins Fontes, São Paulo, 369p.

GREIG-SMITH, P., 1952, The use of random and contiguous quadrats in the study of the structure of plant communities. Ann. Bot., 62: 293-316.

IBGE, 1996, Censo Agropecuário de 1995-1996: Rio Grande do Sul. Disponível em: HYPERLINK < http://www.ibge.gov.br/ ibge/estatistica/agropecuaria/censoagro/43/utiliza.shtm $><$ http://www.ibge.gov.br/ibge/estatistica/agropecuaria/ censoagro/43/utiliza.shtm>. Acesso em: 20 jan. 2001.

JUHÁSZ-NAGY, P. \& PODANI, J., 1983, Information theory methods for the study of spatial processes and sucession. Vegetatio, 51: 129-140.

KEDDY, P., 1993, Do ecological communities exist? A reply to bastow Wilson. J. Veg. Sci., 4: 135-136.

KENKEL, N. C., JUHÁSZ-NAGY, P. \& PODANI, J., 1989, On sampling procedures in populations and community ecology. Vegetatio, 83: 195-207.

KERSHAW, K. A., 1973, Quantitative and dynamic plant ecology. 2. ed., Edward Arnold, London, 308p.

LEVIN, A. S., 1992, The problem of pattern and scale in ecology. Ecology, 73: 1943-1967.

MELLO, O. de, LEMOS, R. C. de, ABRÃO, P. U., AZOLIN, M. A. D., SANTOS, M. da C. L. dos \& CARVALHO, A. P., 1966, Levantamento em série dos solos do Centro Agronômico. Revista da Faculdade de Agronomia e Veterinária da Universidade Federal do Rio Grande do Sul, 8: 7-155.

MOLONEY, K. A., 1993, Determining process through pattern: reality or fantasy? In: S. A. Levin, T. M. Powell \& J. H. Steele, Patch dynamics lecture notes in biomathematics. Springer-Verlag, Berlin, v. 96, pp. 61-69. 
MORENO, J. A., 1961, Clima do Rio Grande do Sul. Secretaria da Agricultura, Porto Alegre, 41p.

MUELLER-DOMBOIS, D. \& ELLENBERG, H., 1974, Aims and methods of vegetation ecology. J. Wiley, New York, 547p.

ORLÓCI, L., 1978, Multivariate analysis in vegetation research. 2. ed., W. Junk Publishers, The Hague, 451p.

ORLÓCI, L., 1993, The complexities and scenarios of ecosystem analysis. In: G. P. Patil \& C. R. Rao (eds.), Multivariate environmental statistics. Elsevier, Amsterdam, pp. 423-432.

PALMER, M. W. \& WHITE, P. S., 1994, On the existence of ecological communities. Journal of Vegetation Science, 5 : 279-282.

PIELOU, E. C., 1984, The interpretation of ecological dataa primer on classification and ordination. John Wiley \& Sons, New York, 263p.

PILLAR, V. D., 1997, Multivariate exploratory analysis and randomization testing with MULTIV. Coenoses, 12: 145148.

PILLAR, V. D., 1999a, The bootstrapped ordination re-examined. J. Veg. Sci., 10: 895-902.

PILLAR, V. D., 1999b, How sharp are classifications? Ecology, 80: 2508-2516.

PILLAR, V. D., 2000a, SYNCSA: software integrado para análise multivariada de comunidades baseada em caracteres, dados de ambiente, avaliação e testes de hipóteses. Departamento de Ecologia, Universidade Federal do Rio Grande do Sul, Porto Alegre (versão para Macintosh).

PILLAR, V. D., 2000b, MULTIV: aplicativo para análise multivariada e testes de hipóteses. Departamento de Ecologia, Universidade Federal do Rio Grande do Sul, Porto Alegre.

PILLAR, V. D., 2001. Suficiência amostral. In: Bicudo, C. \& Bicudo, D. Amostragem em limnologia. Ed. Universidade de Maringá (in press).

PILLAR, V. D. \& BOLDRINI, I. I., 1996, Lindman e a ecologia da vegetação campestre do Rio Grande do Sul. Ciência e Ambiente, 13: 87-97.
PILLAR, V. D., JACQUES, A. V. A. \& BOLDRINI, I., 1992, Fatores de ambiente relacionados à variação da vegetação de um campo natural. Pesq. Agropec. Bras., 27: 1089-1101.

PILlAR, V. D. \& ORLÓCI, L., 1993, Character-based community analysis: the theory and an application program. SPB Academic Publishing, The Hague (Ecological Computations Series; vol. 5).

PILLAR, V. D. \& ORLÓCI, L., 1996, On randomization testing in vegetation science: multifactor comparison of relevé groups. J. Veg. Sci., 7: 585-592.

PODANI, J., 1994, Multivariate data analysis in ecology and systematics. SPB Academic Publishing, The Hague, 316p.

PODANI, J., CZÁRÁN, T. \& BARTHA, S., 1993, Pattern, area and diversity: the importance of spatial scale in species assemblages. Abstracta Botanica, 17: 37-51.

TEDESCO, M. J., GIANELLO, C., BISSANI, C. A., BOHNEN, H. \& VOLKWEISS, S. J., 1995, Análise de solos, plantas e outros materiais. 2. ed., Faculdade de Agronomia, UFRGS, Porto Alegre, 174p.

TREWARTHA, G. T. \& HORN, L. H., 1980, Köppen's classification of climates. In: An Introduction to climate. McGraw-Hill, New York, pp. 397-403.

VAN DER MAAREL, E., 1979, Transformation of coverabundance values in phytosociology and its effects on community similarity. Vegetatio, 39: 97-114.

VAN DER MAAREL, E., 1980, On the interpretability of ordination diagrams. In: van der Maarel (ed.), Classification and ordination. W. Junk Publishers, The Hague, vol. 42, pp. 43-45.

WHITTAKER, R. H., 1967, Gradient analysis of vegetation. Biological Reviews, 42: 207-264.

WIERENGA, P. J., HEINDRICK, J. M. H., NASH, M. H., LUDWIG, J. \& DAUGHERTY, L., 1987, A variation of soil and vegetation with distance along a transect in the Chihuahuan Desert. Journal of Arid Environments, 13: 53-63.

WILSON, J. B. \& CHIARUCCI, A., 2000, Do plant communities exist? Evidence from scaling-up local species-area relations to the regional level. J. Veg. Sci., 11: 773-775. 